\title{
EKSPLORATIF-DESKRIPTIF-EKSPLANATIF DALAM KAJIAN ARKEOLOGI INDONESIA
}

\section{Bugie M.H. Kusumohartono}

Keywords: archaeology; theory; methods; practice; Indonesia

\section{How to Cite:}

Kusumohartono, B. M. (1987). EKSPLORATIF-DESKRIPTIF-EKSPLANATIF DALAM KAJIAN ARKEOLOGI INDONESIA. Berkala Arkeologi, 8(2), 17-26. https://doi.org/10.30883/jba.v8i2.489

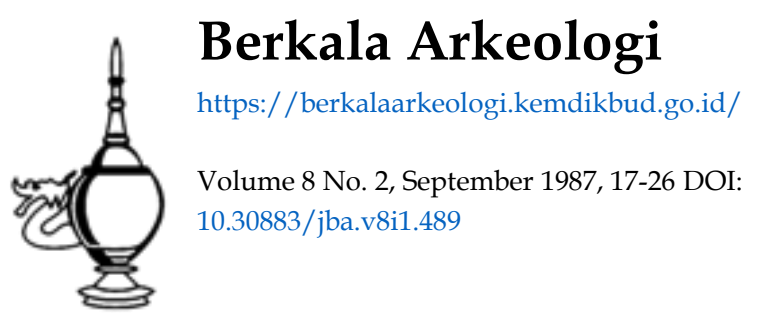




\section{EKSPLORATIF-DESKRIPTIF-EKSPLANATIF DALAM KAJIAN ARKEOLOGI INDONESIA}

Bugie M.H. Kusumohartono

Tulisan ini lahir karena terdorong oleh karya tulis Drs Mundardjito dalam Pertemuan Ilmiah Arkeologi (PIA) IV 1986, yang berjudul Metode Induktif-Deduktif dalam Penelitian Arkeologi di Indonesia. Dalam makalah tersebut disimpulkan bahwa terdapat kecenderungan berpikir induktif dalam penelitian arkeologi Indonesia selama ini dan tercermin pada makalah-makalah PIA (I, II, III). Sehubungan dengan itu Drs. Mundardjito menyodorkan gagasan-gagasan berupa upaya menerapkan penalaran induktif-deduktif dalam penelitian arkeologi untuk pada akhimya dapat secara efektif dan efisien menghasilkan berbagai teori dalam disiplin arkeologi di Indonesia.

Selaras dengan fenomena yang disinyalir oleh Drs. Mundardjito di atas, sangat menarik untuk melakukan pengamatan terhadap tipe-tipe penelitian yang mendasari kertas-kertas kerja PIA I, II, III. Pengamatan terhadap pilihan tipe penelitian tersebut dianggap penting karena dilatarbelakangi oleh dua hal. Pertama, tipe penelitian tertentu berkaitan erat dengan metode atau penalaran yang digunakan. Dengan demikian, pengetahuan kita tentang kecenderungan tipe penelitian yang digunakan oleh makalah-makalah itu sekaligus melengkapi telaah Drs. Mundardjito. Kedua, tidak semua tipe penelitian mampu menelorkan teori, sehingga pengetahuan kita tentang kecenderungan memilih tipe penelitian tertentu juga akan menjelaskan - walaupun secara kasar - latar belakang kekurangefektifan lahirnya teori-teori baru. 
Dalam arkeologi dan juga disiplin ilmu lainnya dikenal tiga tipe pokok penelitian. Ketiga tipe penelitian tersebut adalah eksploratif, deskriptif, dan eksplanatif. Tipe-tipe penelitian tersebut merupakan sari dari lima kategori penelitian yang dikemukakan oleh A.D. de Groot (Gibbon, 1984: 75--83), yaitu: uji hipotesis (hypothesis testing); penyelidikan instrumentasi-nomologik (instrumental-nomological investigations); studi deskriptif (descriptive studies); penyelidikan eksploratori (exploratory investigations); serta studi interpretatif dan teoritik (interpretative and theoritical studies).

Tipe penelitian eksploratif tidak lain adalah penyelidikan eksploratori, yang bertujuan untuk mendapatkan pengetahuan tentang sifat-sifat fenomena penelitian. Penelitian tipe ini bersifat empirik, berlandaskan pada data arkeologi, dan merupakan tahap penjajagan bagi penelitian lebih lanjut. Penelitian eksploratif membantu sekali bagi perumusan masalah yang lebih tajam dan jelas bagi penelitian deskriptif maupun eksplanatif. Sedang khusus bagi penelitian eksplanatif, penelitian eksploratif bermanfaat untuk mengembangkan dan menyempurnakan hipotesis. Penelitian ini sama sekalitidak berangkat dari masalah atau untuk menjawab masalah. Produk dari penelitian eksploratif,

'... do not have to be well supported, just suggestive and stimulating. They are products of an initial process of discovery, not of justification... Therefore, the outcome of an exploratory investigation is never conclusive, and it generally remains of little value unless confronted with new observational data.' (Gibbon, 1984: 79-81).

Penelitian atau studi deskriptif pada dasarnya merupakan upaya untuk menjawab masalah di seputar pertanyaan apa (what) - termasuk juga siapa (who), - di mana (where), dan bila mana (when). Jawaban dalam bentuk kesimpulan atau generalisasi diperoleh melalui deskripsi sistematik dan terklasifikasi terhadap data arkeologi. 
Dengan demikian tipe penelitian ini bersifat fact finding dan empirik, sebagaimana studi etnografi pada disiplin antropologi. Idealnya penelitian deskriptif dilandasi oleh kontrol metodologi yang ketat berupa pencuplikan (sampling), pengamatan (observation), dan statistik (Gibbon, 1984: 77-9).

Penelitian deskriptif berkembang dalam kurun waktu yang panjang di Amerika antara tahun 1840-1960. Tekanar pada masalah kronologi (menjawab pertanyaan when) terasa pada tahun 19141940. Sedang tekanan pada konteks dan fungsi (menjawab pertanyaan what) berlangsung antara tahun 1940-1960 (Willey and Sabloff, 1974: 34-180).

Uji hipotesis maupun studi interpretatif dan teoritik dikategorikan dalam tipe penelitian eksplanatif. Tipe penelitian ini dicirikan oleh keberadaan teori sebagai landasan utama untuk menjawab setiap masalah yang mendorong dilakukannya penelitian. Dari teori diturunkanlah hipotesis yang akan diuji secara empirik. Perlu di. sampaikan terlebih dahulu, bahwa yang dimaksudkan dengan teori adalah

'... a set of interrelated, rather high-level principles or laws that can provide an explanatory framework to accomodate a broad range of phenomena'. (Salmon, 1982: 140).

Dengan demikian teori selalu terdiri atas sekurangnya dua variabel, yaitu high-level principles or laws sebagai variabel bebas (independent variable) dan phenomena sebagai variabel gayut (dependent variabel).

Sebagaimana teori, hipotesis pun dengan sendirinya merupakan pernyataan yang memperlihatkan kaitan penjelasan suatu kaidah umum terhadap suatu fenomena atau masalah tertentu (Watson, Le Blanc, and Redman, 1984: 7). Kebenaran suatu hipotesis masih bersifat spekulatif sampai dengan terselesaikannya tahap pengujian (verification).

Studi interpretatif dan teoritik dikategorikan sebagai penelitian eksplanatif karena unsur utamanya adalah penjelasan. Dengan demi- 
kian terdapat pula di dalamnya hipotesis dan teori. Hanya saja, perhatian lebih diarahkan pada upaya untuk melahirkan interpretasi baru guna meningkatkan derajat keterdukungan teori (Gibbon, 1984: 81-2).

Secara umum tipe penelitian eksplanatif berorientasi pada masalah mengapa (why) atau bagaimana (how) sebagai titik tolaknya. Penelitian eksplanatif mulai berkembang pesat di Amerika sejak 1960 hingga kini (Willey and Sabloff, 1974: 181-264). Tipe penelitian ini merupakan pilihan utama karena beberapa pakarnya menganggap eksplanasi lebih dapat dipertanggungjawabkan secara ilmiah (scientific) (Watson, Le Blanc, and Redman, 1984).

Penyelidikan instrumental-nomologik tidak akan dibicarakan secara khusus karena sifat dan tujuannya berada di luar landasan telaah ini. Penelitian tipe ini lebih ditujukan untuk memantapkan gagasan teoritik mengenai pengukuran, baik dalam hal penyusunan, penyeragaman, maupun keterandalannya (Gibbon, 1984: 76). Hasil dari penelitian inilah yang nantinya digunakan bagi kepentingan penelitian deskriptif maupun eksplanatif.

III

Selaras dengan keterbatasan yang ada, serta dalam kaitannya dengan kertas kerja Drs. Mundardjito, data dibatasi hanya pada makaiah PIA I, II, dan III. 175 makalah yang disajikan dalam ketiga PIA tersebut akan dirinci atas tipe eksploratif, deskriptif, eksplanatif, dan 'lain-lain'. Yang dimaksud dengan tipe 'lain-lain' adalah makalah yang bercirikan:

1. Menyajikan topik tentang metodologi, teori, teknik, atau gagasan baru. Pada umumnya makalah tersebut tidak menggunakan data arkeologi sebagai kajiannya.

2. Ditulis oleh pakar asing dan umumnya mengenai masalah arkeologi bukan Indonesia.

3. Ditulis oleh pakar Indonesia tetapi mengenai masalah arkeologi bukan Indonesia. 
Pemilahan makalah-makalah PIA I, II, dan if ke dalam tiga tipe penelitian bukanlah aktivitas yang sederhana. Sebagian besar makalah memperlihatkan ketumpang tindihan dalam hal pilihan tipe penelitiannya. Dengan demikian terdapat beberapa kertas kerja yang memperlihatkan kedudukannya : 1. Di antara tipe penelitian eksploratif dan deskriptif, dan 2. Di antara tipe penelitian deskriptif dan eksplanatif. Makalah-makalah butir 1 pada umumnya dikategorikan ke dalam tipe deskriptif, sedang butir 2 dikategorikan ke dalam tipe eksplanatif.

Kesulitan utama untuk memilahkan makalah-makalah tersebut secara tegas ke dalam masing-masing tipe penelitian disebabkan karena pilihan atas tipe penelitian tertentu tidak disajikan secard eksplisit. Oleh karenanya identifikasi terhadap tipe-tipe penelitian yang digunakan dalam makalah-makalah tersebut didasarkan atas judul, alur pemikiran, maupun hasil akhir penelitian.

PIA I menyajikan 35 makalah dengan rincian yang memper-

PIA I

\begin{tabular}{lcccccc}
\hline \multicolumn{1}{c}{ Tipe } & $\begin{array}{c}\text { Eksplo- } \\
\text { ratif }\end{array}$ & $\begin{array}{c}\text { Des- } \\
\text { kriptif }\end{array}$ & $\begin{array}{c}\text { Ekspla- } \\
\text { natif }\end{array}$ & $\begin{array}{c}\text { 'Lain- } \\
\text { lain' }\end{array}$ & Jumlah \\
\hline Prasejarah & 5 & 3 & - & - & 8 \\
Klasik & 8 & & 5 & - & 1 & 14 \\
Islam & 3 & & 1 & - & - & 4 \\
Aneka Ragam & 2 & & 4 & - & 3 & 9 \\
Jumlah & 18 & & 13 & - & 4 & 35 \\
\hline & $(51.43 \%)$ & $(37.14 \%)$ & & $(11.43 \%)$ & $(100 \%)$
\end{tabular}

lihatkan dominasi penelitian eksploratif $(51.43 \%)$ sebagai pilihan utama. Tidak berbeda jauh dengan prosentase pilihan tipe ini, sebagian yang lain $(37.14 \%)$ menyajikan penelitian deskriptif. Sementara itu tipe penelitian eksplanatif tidak dijumpai di antara makalahmakalah PIA I tersebut. 
PIA Il memperlihatkan peningkatan jumlah kertas kerja sebanyak $45 \%$. Namun demikian kecenderungan utama masih diperlihatkan oleh tipe penelitian eksploratif (50.9\%), lalu disusul oleh

\section{PIA II}

\begin{tabular}{lccccc}
\hline Jenis & $\begin{array}{c}\text { Eksplo- } \\
\text { ratif }\end{array}$ & $\begin{array}{c}\text { Des- } \\
\text { kriptif }\end{array}$ & $\begin{array}{c}\text { Ekspla- } \\
\text { natif }\end{array}$ & $\begin{array}{c}\text { 'Lain- } \\
\text { lain' }\end{array}$ & Jumlah \\
\hline Prasejarah & 6 & 2 & 1 & - & 9 \\
Klasik & 11 & 8 & - & 2 & 21 \\
Islam & 2 & 1 & - & - & 3 \\
Aneka Ragam & 7 & 7 & - & 4 & 18 \\
\hline Jumlah & 26 & 18 & 1 & 6 & 51 \\
\hline & $(50.98 \%)$ & $(35.29 \%)$ & $(1.96 \%)$ & $(11.77 \%)$ & $(100 \%)$
\end{tabular}

tipe deskriptif (35.29\%). Adalah menarik bahwa sebuah makalah $(1.96 \%)$ memperlihatkan ciri penelitian eksplanatif. Memang kertas kerja ini tidak secara tuntas mengoperasionalisasikan aktivitas eksplanasinya, sehingga hasil utamanya berupa eksplanasi atau penje lasan belum sepenuhnya nampak. Namun demikian gambaran eksplisit tentang langkah-langkah penelitian yang dipilihnya memilikı ciri tipe penelitian eksplanatif. 
PIA III memperlihatkan peningkatan jumlah kertas kerja se. PIA III

\begin{tabular}{lccccc}
\multicolumn{7}{c}{ Tipe } & $\begin{array}{c}\text { Eksplo- } \\
\text { ratif }\end{array}$ & $\begin{array}{c}\text { Des- } \\
\text { kriptif }\end{array}$ & $\begin{array}{c}\text { Ekspla- } \\
\text { natif }\end{array}$ & $\begin{array}{c}\text { 'Lain- } \\
\text { lain' }\end{array}$ & Jumlah \\
\hline Jenis & 11 & 4 & - & - & 15 \\
Prasejarah & 15 & 17 & - & 1 & 33 \\
Ilasik & 3 & 4 & - & 1 & 8 \\
Etam & 6 & 3 & - & - & 9 \\
Paleoanktropologi & 1 & 2 & - & - & 3 \\
Paleoekologi/ & 2 & 4 & - & - & 6 \\
geologi & 3 & 1 & - & - & 4 \\
Keramik & 2 & - & - & 9 & 11 \\
Aneka Ragam & 2 & - & - & 11 & 89 \\
\hline Jumlah & 43 & 35 & & $(12.36 \%)$ & $(100 \%)$
\end{tabular}

banyak $75 \%$. Tidak berbeda dengan komposisi pilihan tipe penelitian pada PIA II, kecenderungan utama diperlihatkan oleh tipe penelitian eksploratif $(48.31 \%)$ dan kemudian tipe penelitian deskriptif $(39.33 \%)$. Hanya saja dalam PIA III tidak terdapat pilihan tipe penelitian eksplanatif.

Dari 175 kertas kerja dalam tiga kali PIA tersebut, komposisi menyeluruh memperlihatkan kecenderungan demikian :

\begin{tabular}{|c|c|c|c|c|c|}
\hline PIA Tipe & $\begin{array}{l}\text { Eksplo- } \\
\text { ratif }\end{array}$ & $\begin{array}{c}\text { Des- } \\
\text { kriptif }\end{array}$ & $\begin{array}{l}\text { Ekspla- } \\
\text { natif }\end{array}$ & $\begin{array}{l}\text { 'Lain- } \\
\text { lain' }\end{array}$ & Jumlah \\
\hline PIA I & 18 & 13 & - & 4 & 35 \\
\hline PIA II & 26 & 18 & 1 & 6 & 51 \\
\hline PIA III & 43 & 35 & - & 11 & 89 \\
\hline \multirow[t]{2}{*}{ Jumlah } & 87 & 66 & 1 & 21 & 175 \\
\hline & $(49.7 \%)$ & $(37.7 \%)$ & $(0.6 \%)$ & $(12 \%)$ & $(100 \%)$ \\
\hline
\end{tabular}

Berkala Arkeologi VIII (2) 
Sebagian besar kertas kerja memperlihatkan kecenderungan penelitian eksploratif (49.7\%) dan sebagiān yang lain menerapkan penelitian deskriptif (37.7\%). Prosentase yang amat rendah ditunjukkan oleh penggunaan tipe penelitian eksplanatif $(0.6 \%)$, yang berarti satu dari 175 makalah yang diajukan. Makalah 'lain-lain' mencapai prosentase $12 \%$, besaran yang relatif konstan selama ketiga PIA tersebut.

Tiga tipe pokok penelitian di atas - eksploratif, deskriptif, dan eksplanatif - setidaknya dapat dibandingkan dengan tiga tahap hirarkis penelitian yang dikemukakan oleh Gordon R. Willey dan Philip Philips (Thomas, 1974: 57-8). Ketiga tahap hirarkis penelitian tersebut adalah observasi, deskripsi, dan eksplanasi. Penelitian observasi berkenaan dengan aktivitas empirik (field work). Kemudian pada tahap deskripsi, fakta-fakta yang diperoleh dalam penelitian diintegrasikan ke dalam alur sejarah budaya. Tahap yang paling atas dalam struktur hirarki adalah eksplanasi yang menekankan pada integrasi proses budaya.

Dalam kaitan ini Robert J. Sharer dan Wendy Ashmore menyatakan bahwa terdapat kesejajaran antara penelitian deskriptif untuk mengungkapkan sejarah kebudayaan dengan pemanfaatan penalaran induktif,

The research method associated with the cultural historical approach is inductive, beginning with specific data from individual sites and combining these in increasing degrees of generalization and synthesis'. (Sharer and Ashmore, 1979: 484-90).

Selanjutnya dinyatakan pula bahwa penelitian eksplanatif untuk menjelaskan proses kebudayaan lebih memperlihatkan relevansi dengan penalaran deduktif,

'The basic data gathering procedures used in the cultural processual approach are the same as those used for cultural historical reconstruction, but the orientation of research is critically different: the overall strategy is deductive rather than inductive. In practice, this means that research begins with the formulation of the propositions to be tested and the definition of relevan data - those kinds of data that provide appropriate tests for the propositions'. (Sharer and Ashmore, 1979: 513--6) 
Dengan demikian kecenderungan penalaran induktif sebagaimana dijumpai oleh Drs. Mundardjito (1986) dapat dipahami karena di pihak lain makalah-makalah tersebut cenderung pula untuk bersandar pada studi deskriptif. Bahkan apabila dicermati, maka tidak semua makalah tersebut menggunakan penalaran induktif karena sebagian merupakan penelitian eksploratif. Sebagaimana telah disampaikar. di depan, hasil akhir dari penelitian eksploratif belum merupakan suatu konklusi atau generalisasi.

Pengembangan penelitian eksplanatif dengan pendekatan proses kebudayaan dan penerapan penalaran deduktif (maupun induktifdeduktif) diharapkan akan semakin berkembang pada masa mendatang. Terwujudnya harapan ini jelas akan memacu lahirnya teoriteori arkeologi Indonesia secara cepat, dapat diandalkán, dàn efisien. 


\section{RUJUKAN}

GIBBON, Guy. 1984. Anthropological Archaeology. New York: Columbia University Press.

MUNDARDJITO. 1986. Metode Induktif-Deduktif dalam Penelitian Arkeologi di Indonesia . PIA, IV (III. Konsepsi dan Metodologi). Jakarta : Puslit Arkenas.

PERTEMUAN Ilmiah Arkeologi, I. Cibulan, 21-25 Februari 1977. Jakarta: 1980 PUSP3N.

PERTEMUAN Ilmiah Arkeologi , II. Jakarta, 25-29 Februari 1980. Jakarta : 1982 Puslit Arkenas.

PERTEMUAN Ilmiah Arkeologi , III. Ciloto, 23-28 Mei 1983 . 1985. Jakarta: Puslit Arkenas.

SALMON, Merrilee H. 1982. Philosophy and Archaeology. New York: Academic Press.

SHARER, Robert J. and Wendy Ashmore. 1979. Fundamentals of Archaeology. California : Benyamin/Cumming Publishing Co.

THOMAS, David Hurst. 1974. Predicting the Past, An Introduction of Anthropological Archaeology. New York: Holt, Reinhart and Winston Inc.

WATSON, Patty Jo ; Steven Le Blanc; and Charles Redman. 1984. Archaeological Explanation, The Scientific Method in Archaeology. New York: Columbia University Press.

WILLEY, Gordon R and Jeremy A Sabloff . 1974. A History of American Archaeology. San Fransisco: W.H. Freeman and Co. 